\title{
Spatial-temporal distribution of phytophagous and predatory mites in the canopy of Jatropha curcas L.*
}

\author{
Distribuição espaço-temporal de ácaros fitófagos \\ e predadores no dossel de plantas de pinhão-manso
}

\author{
Althieris de Souza Saraiva', Renato de Almeida Sarmento ${ }^{2 * *}$ (D), Marçal Pedro-Neto², \\ Eduardo Andrea Lemus Erasmo ${ }^{2}$, Adenir Vieira Teodoro ${ }^{3}$
}

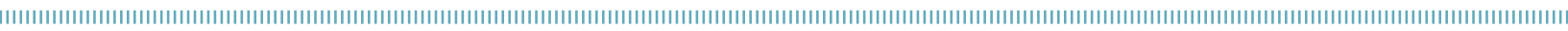

\begin{abstract}
The aim of the present study was to evaluate the spatial-temporal distribution of phytophagous and predatory mites in the canopy of Jatropha curcas L. Mite richness, diversity, and abundance were determined, and higher values were observed primarily in the top stratum. Mite population in J. curcas was higher during the rainy season. Phytophagous mites were mostly concentrated in the top stratum, and Brevipalpus sp. was the most abundant. Predatory mites from the family Phytoseiidae presented the highest richness and diversity, and Amblydromalus zannoui was the most abundant species. The present results indicate seasonal population dynamics for both predatory and phytophagous mites on J. curcas.
\end{abstract}

KEYWORDS: physic nut plants; mite integrated management; monitoring; Amblydromalus zannoui.
RESUMO: O presente estudo teve por objetivo avaliar a distribuição espaço-temporal de ácaros fitófagos e predadores no dossel de plantas de pinhão-manso. Parâmetros de riqueza, diversidade e abundância de ácaros foram determinados. Os resultados deste estudo demonstram que maiores valores de riqueza, diversidade e abundância de ácaros foram observados principalmente no estrato apical e que os níveis populacionais desses artrópodes em plantas de pinhão-manso são mais expressivos na estaçáo chuvosa. Os ácaros fitófagos concentram-se distribuídos principalmente no estrato apical, sendo Brevipalpus sp. a espécie mais abundante. Ácaros predadores da família Phytoseiidae foram aqueles de maior riqueza e diversidade, sendo o ácaro predador Amblydromalus zannoui o mais abundante. Os resultados obtidos neste trabalho sugerem uma dinâmica sazonal tanto para populações de ácaros predadores quanto para ácaros fitófagos em pinhão-manso.

PALAVRAS-CHAVE: Jatropha curcas L.; manejo integrado de ácaros; monitoramento; Amblydromalus zannoui.

\footnotetext{
'Departamento de Agropecuária (Conservação de Agroecossistemas e Ecotoxicologia), Instituto Federal de Educação, Ciência e Tecnologia Goiano, campus Campos Belos - Campos Belos (GO), Brazil

${ }^{2}$ Universidade Federal do Tocantins - Palmas (TO), Brazil

${ }^{3}$ Embrapa Tabuleiros Costeiros - Aracaju (SE), Brazil

*This article is part of the dissertation of the first author.

**Corresponding author: rsarmento@uft.edu.br

Received on: 02/28/2018. Accepted on: 09/10/2018

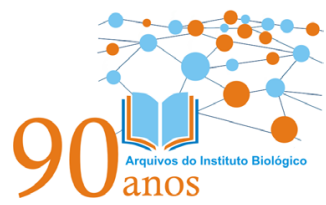




\section{INTRODUCTION}

Considering the potential use of Jatropha curcas L. for biofuel production (ALONSO; LEZCANO, 2014), integrated management studies of pest arthropods associated with this crop are necessary for optimizing its production. For example, phytophagous mites are usually reported to be potential pests of J. curcas (SARMENTO et al., 2011; CRUZ et al., 2013a; LOFEGO et al., 2013; PEDRO-NETO et al., 2013; ROSADO et al., 2015a; 2015b; SARAIVA et al., 2015). Predatory mites, especially those in the family Phytoseiidae, also colonize J. curcas plants and play a key role in limiting phytophage population (SARMENTO et al., 2011). These mites may therefore provide natural biological control of phytophagous mites in J. curcas.

Seasonality may affect arthropod distribution and population density in the field (ZUNDEL et al., 2009), and climatic factors such as rainfall and temperature affect the population dynamics of phytophagous and predatory mites present in agricultural crops (PEDRO-NETO et al., 2010; CRUZ et al., 2013b; ROSADO et al., 2015a). Rainfall, relative humidity, and temperature are important explanatory mechanisms for abundance of the mite community colonizing J. curcas (CRUZ et al., 2013b).

Occurrence of the mite community may vary with plant size and between different plant parts due to differing levels of solar incidence, wind, humidity, and other abiotic factors, which directly affect the acarofauna present on the crop (FERES et al., 2010). For example, mites from the family Tarsonemidae prefer the younger leaves at the top of the plant, whereas mites from the family Tetranychidae are found more commonly on the lower side of fully developed J. curcas leaves than on younger leaves (MORAES; FLECHTMANN, 2008; SARMENTO et al., 2011; ROSADO et al., 2014).

The aim of the present study was to evaluate the spatial and temporal distribution of acarofauna associated with J. curcas.

\section{MATERIALS AND METHODS}

The study was conducted between December 2011 and November 2012 in an experimental plantation of J. curcas (spacing $2 \times 3 \mathrm{~m}$ ) at the Federal University of Tocantins (Universidade Federal do Tocantins - UFT), University Campus of Gurupi, located in the southern portion of the state of Tocantins, Brazil, at the altitude of $280 \mathrm{~m}$, latitude $11^{\circ} 43^{\prime} \mathrm{S}$ and longitude $49^{\circ} 04^{\prime} \mathrm{W}$. Based on rainfall, the rainy season was considered from December 2011 (beginning of evaluations) to April 2012, as well as the month of November 2012, while May to October 2012 was considered the dry season (Fig. 1); rainfall was lower than the historical average for the municipality of Gurupi, Tocantins, Brazil.
From J. curcas within the plantation, 120 plants were randomly selected for sampling. The selected plants were standardized by pruning at $80 \mathrm{~cm}$ from the ground, followed by topdressing and fertilization every 30 days with $200 \mathrm{~g} /$ plant of NPK 10-10-10. The first evaluations of mite population variations were performed when branches were 30 days old. Populations were evaluated within the top, medium, and bottom strata (treatments) of the J. curcas plants, and three leaves per stratum were collected from each plant. Leaves were collected from the upper quarter of the branch (fourth to eighth fully expanded leaf).

Leaf collections were performed on a monthly basis for one year, always during the morning. After collection, leaves were identified and placed in transparent plastic bags, and then transported to the laboratory, where they were washed in a 325-mesh sieve (SPONGOSKI et al., 2005). When leaves could not be washed on the day of collection, they were stored at $4^{\circ} \mathrm{C}$ until the following day. The residues were stored in microtubes (Eppendorf, Hamburg, Germany) containing 70\% alcohol, and mite abundance was evaluated.

Specimens were mounted on slides using Hoyer's medium and evaluated using a stereo microscope. Specimen identification was performed using the dichotomous keys by CHANT; MCMURTRY (1994), LOFEGO (1998), and MORAES et al. (2004) for mites from the family Phytoseiidae; PRITCHARD; BAKER (1995) and BOLLAND et al. (1998) for mites from the family Tetranychidae; WELBOURN et al. (2003) for mites from the family Tenuipalpidae; GERSON et al. (1999) for mites from the family Cheyletidae; and HALLIDAY et al. (1998) for mites from the families Ascidae and Blattisocidae. Slides were deposited in the collection of the laboratory of Functional and Applied Ecology of UFT.

Species accumulation curves were generated using the Mao Tau estimator, obtained using the software EstimateS version

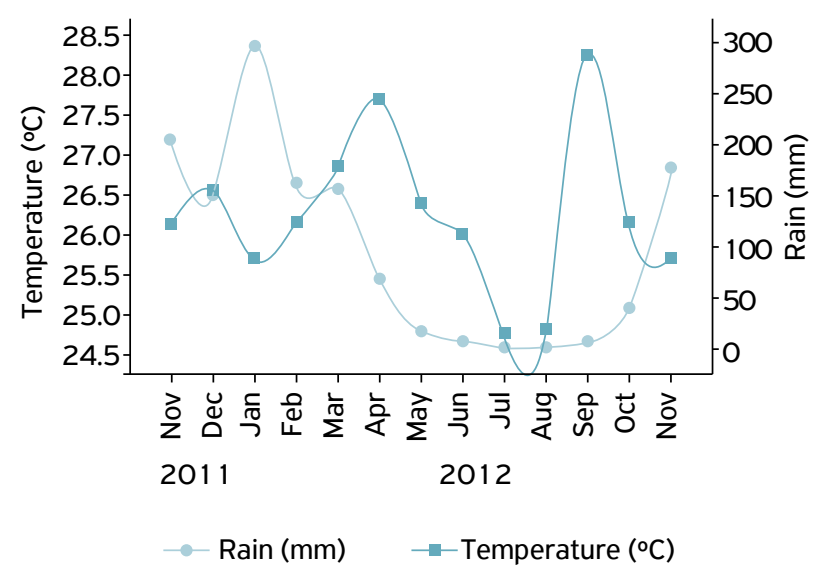

Source: National Institute of Meteorology (Instituto Nacional de Meteorologia - INMET)/Federal University of Tocantins (Universidade Federal do Tocantins - UFT).

Figure 1. Average temperature and rainfall in Gurupi, Tocantins, Brazil, from November 2011 to November 2012. 
7.52. The Shannon-Wiener diversity index (H') (SHANNON, 1948) was calculated separately for total (phytophagous + predatory), phytophagous, and predatory mite species, using the Equation 1:

$\mathrm{H}^{\prime}=-\Sigma \mathrm{p}_{\mathrm{i}} \bullet\left(\ln \mathrm{p}_{\mathrm{i}}\right)$

In which:

$\mathrm{p}_{\mathrm{i}}=$ the proportion of each species in the community.

Evenness $\left(\mathrm{e}^{\mathrm{H}^{\prime}}\right)$, which is the distribution pattern of individuals between species, was calculated to determine the homogeneity and uniformity of species distribution within the mite community.

Mite abundance (total, predatory, and phytophagous mites) in the different strata of J. curcas plants was analyzed using the non-parametric Kruskal-Wallis test. Mite abundances in the different strata of $J$. curcas plants during the dry and rainy season were compared using repeated measures ANOVA. Data was $\log (x+1)$ transformed. All analyses were performed using the Statistica 8.0 software.

\section{RESULTS AND DISCUSSION}

Collected mites were grouped into families and identified according to feeding habit as either phytophagous (Tarsonemidae, Tenuipalpidae, and Tetranychidae) or predatory (Ascidae, Blattisociidae, Cheyletidae, and Phytoseiidae) (Table 1). Phytoseiidae was the most diverse family, with 10 species, and Brevipalpus sp. (Acari: Tenuipalpidae) had the highest occurrence among phytophagous species, especially in the top stratum.

The number of mites was relatively low when compared to other studies performed in the state of Tocantins (Table 1) (SARMENTO et al., 2011; CRUZ et al., 2012; 2013a; 2013b; ROSADO et al., 2014; ROSADO et al., 2015a). However, a study performed during the same agricultural year (2011/2012) as the present study (SARAIVA et al., 2015) also observed a low occurrence of phytophagous and predatory mites associated with $J$. curcas. This indicates seasonal dynamics for both predatory and phytophagous mite populations of J. curcas (ROSADO et al., 2015a).

Phytophagous mites of Brevipalpus sp. may affect their host plants directly or indirectly, namely by transmitting diseases

Table 1. Richness of phytophagous and predatory mites in the top, medium, and bottom canopy strata of Jatropha curcas plants in the dry and rainy season. Gurupi, Tocantins, Brazil, $2011 / 2012$.

\begin{tabular}{|c|c|c|c|c|c|c|c|}
\hline \multirow{3}{*}{ Species } & \multirow{3}{*}{ Family } & \multicolumn{3}{|c|}{ Rainy season } & \multicolumn{3}{|c|}{ Dry season } \\
\hline & & \multicolumn{6}{|c|}{ Canopy strata of physic nut plants } \\
\hline & & Top & Medium & Bottom & Top & Medium & Bottom \\
\hline \multicolumn{8}{|l|}{ Phytophagous } \\
\hline Brevipalpus sp. & Tenuipalpidae & 4 & 1 & 2 & 13 & 6 & 2 \\
\hline Tetranychus sp. & Tetranichydae & 0 & 0 & 0 & 1 & 0 & 0 \\
\hline Tarsonemus sp. & Tarsonemidae & 1 & 0 & 0 & 1 & 0 & 0 \\
\hline \multicolumn{8}{|l|}{ Predators } \\
\hline Amblydromalus zannoui & Phytoseiidae & 2 & 3 & 2 & 5 & 1 & 1 \\
\hline Amblydromalus limonicus & Phytoseiidae & 1 & 0 & 0 & 0 & 0 & 0 \\
\hline Cheletogenes ornatus & Cheyletidae & 0 & 1 & 0 & 0 & 0 & 0 \\
\hline Asca sp. & Ascidae & 1 & 2 & 4 & 0 & 1 & 0 \\
\hline Asca germani & Ascidae & 0 & 0 & 1 & 0 & 0 & 0 \\
\hline Amblyseius sp. & Phytoseiidae & 2 & 0 & 0 & 0 & 0 & 0 \\
\hline Amblyseius compositus & Phytoseiidae & 1 & 0 & 1 & 0 & 0 & 0 \\
\hline Amblyseius neochiapensis & Phytoseiidae & 0 & 0 & 0 & 1 & 0 & 1 \\
\hline Amblyseius acalyphus & Phytoseiidae & 0 & 0 & 0 & 0 & 0 & 1 \\
\hline Euseius citrifolius & Phytoseiidae & 0 & 1 & 1 & 0 & 0 & 0 \\
\hline Neoseiulus sp. & Phytoseiidae & 0 & 0 & 0 & 0 & 1 & 0 \\
\hline $\begin{array}{l}\text { Proprioseiopsis } \\
\text { neotropicus }\end{array}$ & Phytoseiidae & 0 & 0 & 0 & 1 & 0 & 1 \\
\hline Não identificado & Phytoseiidae & 1 & 0 & 0 & 1 & 1 & 0 \\
\hline Aceodromus sp. & Blattisociidae & 1 & 0 & 0 & 0 & 0 & 0 \\
\hline Aceodromus convolvuli & Blattisociidae & 0 & 0 & 1 & 0 & 0 & 0 \\
\hline
\end{tabular}


to crops such as citrus trees and coffee plants (MORAES; FLECHTMANN, 2008). The higher occurrence of Brevipalpus $\mathrm{sp}$. in J. curcas may be related, at least partly, to the spontaneous presence within the plantation of plants which may act as hosts for this mite (CRUZ et al., 2013a). It should be highlighted that, despite this high occurrence, there are no reports of diseases transmitted by this mite to this crop.

Mites from the family Phytoseiidae (67\% of the species found) were the predatory mites with highest richness (Table 1) and abundance (Figs. 2A, 2B and 2C) in all strata of the $J$. curcas plants. A new species of predatory mite belonging to this family was identified and subsequently described as Amblydromalus zannoui (SOURASSOU et al., 2017). This species stood out as the most abundant species within the top stratum of $J$. curcas plants. Amblydromalus zannoui is closely related to $A$. manihoti and A. limonicus (Acari: Phytoseiidae), which have been successfully used in biological control programs worldwide. Therefore, the association of $A$. zannoui with phytophagous mites in J. curcas (CRUZ et al., 2012; 2013a; 2013b; SARAIVA et al., 2015) justifies future study of the potential practical use of this new predatory mite species in biological control of pest-mites in J. curcas.

Based on their feeding behavior (with regard to their prey), predatory mites in the family Phytoseiidae benefit from increased numbers of phytophagous mites on the crop. For example, phytoseiid mites such as Iphiseiodes zuluagai Denmark \& Muma and Euseius concordis (Chant) are usually associated with Tetranychus bastosi (Tuttle, Baker \& Sales) in J. curcas plantations in the southern state of Tocantins, Brazil (SARMENTO et al., 2011). The observed higher richness and abundance of predatory mites from the family Phytoseiidae may also relate to the diversity of spontaneous plants inside the plantation, as they provide alternative sources of food and shelter for these mites (FERLA et al., 2007).

Wealth of mites in physic nut plants [top - medium - bottom]
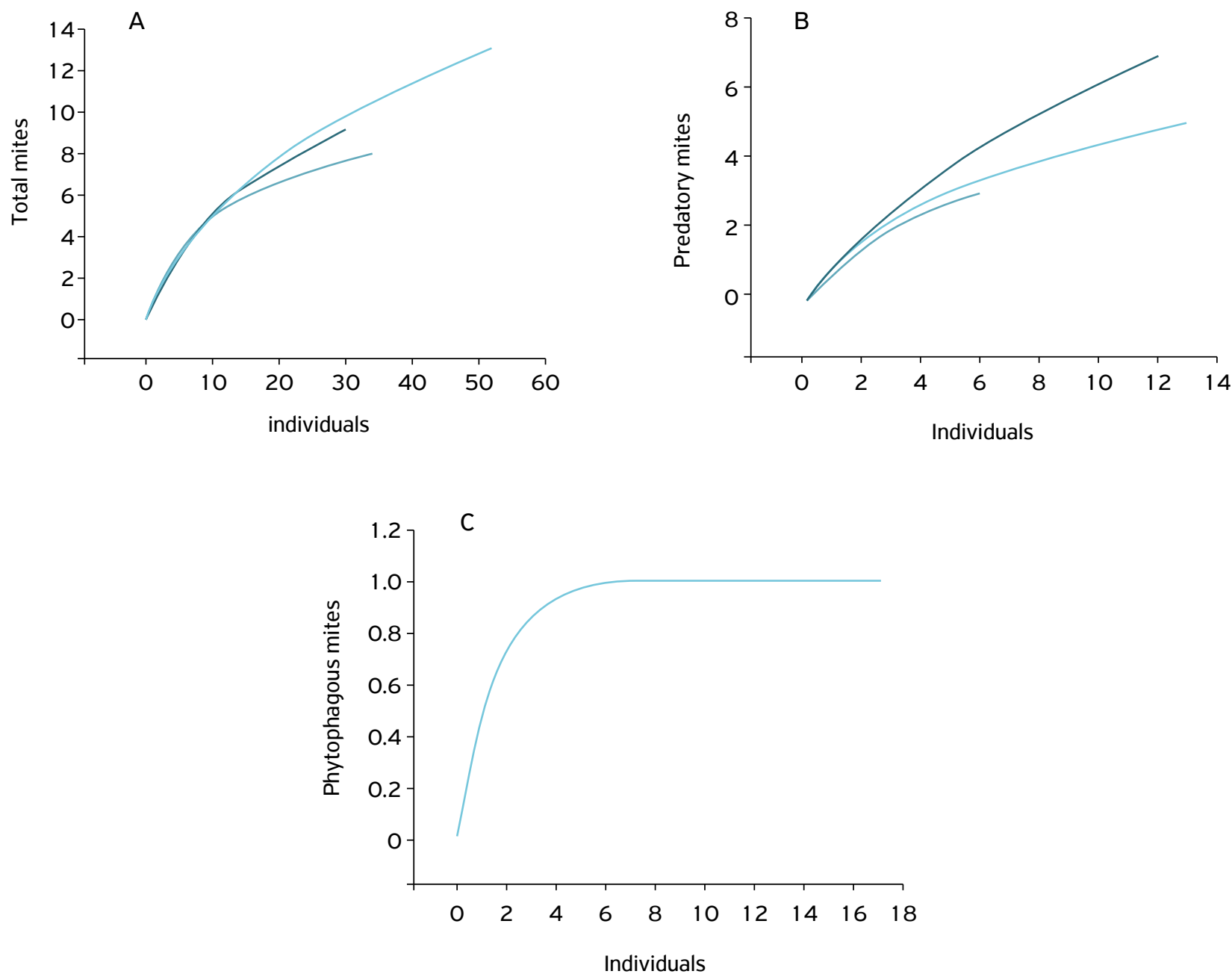

Figure 2. Species accumulation curves standardized by: (A) the total number of mites (predator + phytophagous); (B) the number of predatory mites; $(C)$ the number of phytophagous mites. Evaluations performed in the top, medium, and bottom canopy strata of Jatropha curcas plants. 
The higher richness and abundance of phytophagous mites in the top stratum of J. curcas plants indicates a level of specificity, or feeding preference for younger leaves, and resulted in an available food source (phytophagous mites) for predatory mites, which was surely a factor in their higher occurrence within the top stratum of $J$. curcas plants.

Mite diversity in the different strata of $J$. curcas plants, measured using the Shannon-Wiener index (H'), was the highest (total - predatory and phytophagous) in the top stratum $\left(\mathrm{H}^{\prime}=2.058 ; \mathrm{e}^{\mathrm{H}^{\prime}}=7.840\right)$, followed by the medium $\left(\mathrm{H}^{\prime}=1.908 ; \mathrm{e}^{\mathrm{H}}=6.748\right)$ and bottom stratum $\left(\mathrm{H}^{\prime}=1.778\right.$; $\left.\mathrm{e}^{\mathrm{H}}=5.925\right)$. Predatory mite species diversity was higher in the bottom stratum $\left(\mathrm{H}^{\prime}=2.008 ; \mathrm{e}^{\mathrm{H}^{\prime}}=7.458\right)$, followed by the top $\left(\mathrm{H}^{\prime}=1.615 ; \mathrm{e}^{\mathrm{H}}=5.033\right)$ and medium stratum $\left(\mathrm{H}^{\prime}=1.380\right.$; $\mathrm{e}^{\mathrm{H}}$ ' $\left.=3.978\right)$. Phytophagous mite diversity was the highest in

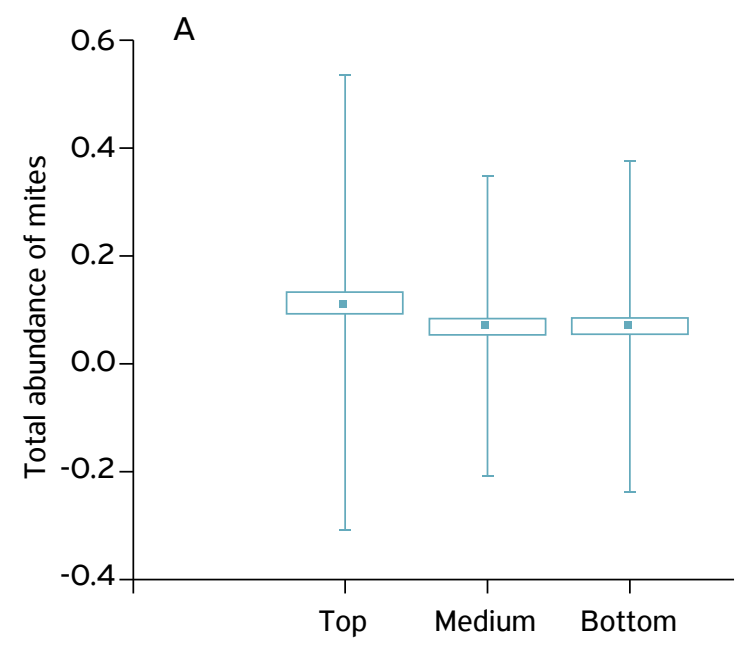

the top stratum $\left(\mathrm{H}^{\prime}=0.518 ; \mathrm{e}^{\mathrm{H}^{\prime}}=1.679\right)$, followed by the medium stratum $\left(\mathrm{H}^{\prime}=0.377 ; \mathrm{e}^{\mathrm{H}^{\prime}}=1.458\right)$, with no species diversity in the bottom stratum $\left(\mathrm{H}^{\prime}=0 ; \mathrm{e}^{\mathrm{H}^{\prime}}=1.0\right)$.

Total, predatory, and phytophagous mite abundances were not affected by canopy stratum ( $\mathrm{p}>0.05$; Figs. 3A, 3B and 3C). No significant differences in total mite abundance were observed between the different canopy strata (Fig. 4A), or in the interaction between season (rainy or dry) and canopy stratum ( $p>0.05$ ). However, the total abundance of mite species was significantly affected by the rainy season ( $\mathrm{p}<0.01$; Fig. $4 \mathrm{~A})$, which was related to the higher rainfall during this period.

Predatory mite abundance (Fig. 4B) was not affected by canopy stratum or season, or by interaction between these two factors ( $p>0.05$; Fig. 4B). In contrast, phytophagous mite abundance was significantly higher during the rainy season

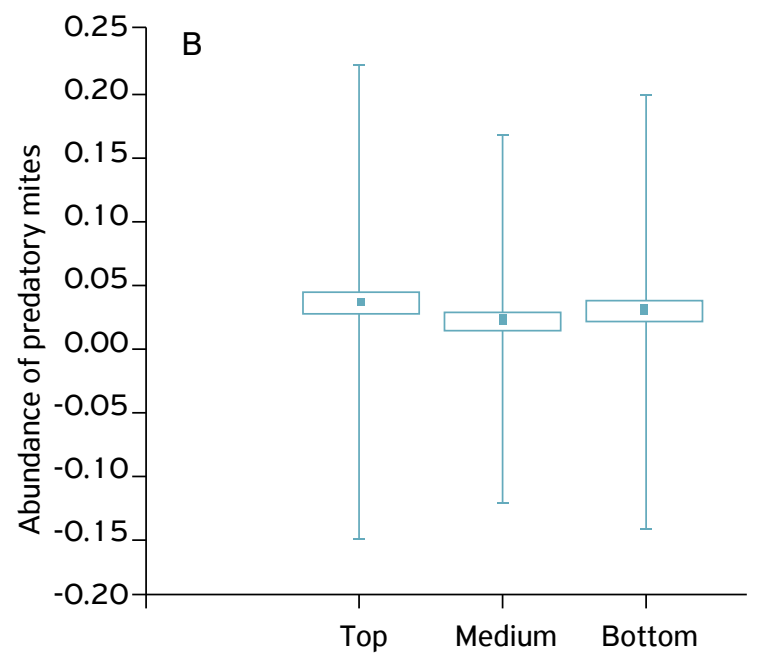

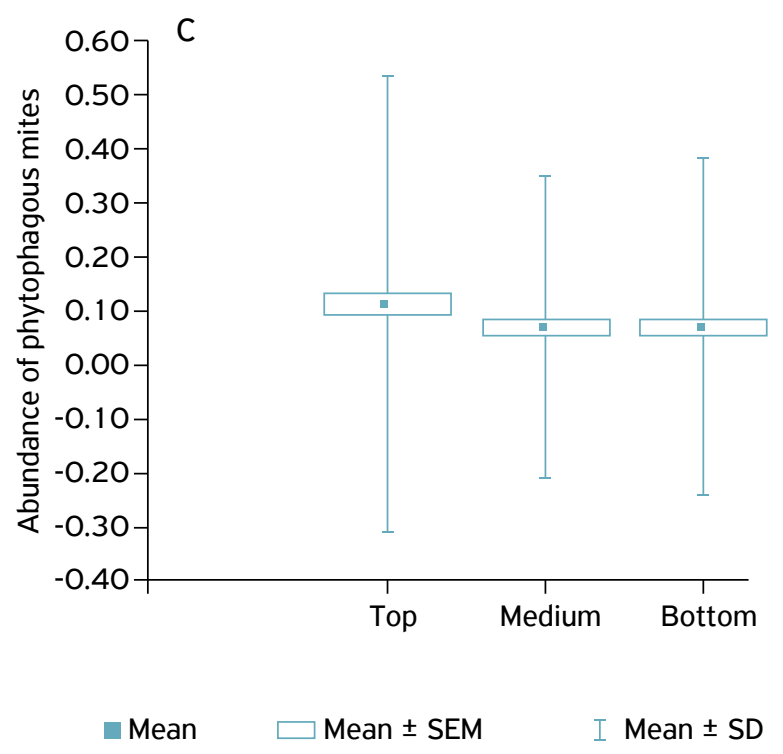

SEM: standard error mean; SD: standard deviation; Df: degrees freedom.

Figure 3. Total mite abundance $(A)\left(X^{2}=3.47, D f=2, p=0.17\right)$; predatory mite abundance $(B)\left(X^{2}=1.857773, D f=2, p=0.39\right)$; and phytophagous mite abundance $(C)\left(X^{2}=1.25, \mathrm{Df}=2, \mathrm{p}=0.53\right)$. Evaluations performed in the top, medium, and bottom canopy strata of Jatropha curcas plants. 
$(\mathrm{p}<0.01)$, although it was not affected by canopy stratum or by interaction between stratum and season ( $p>0.05$; Fig. 4C). J. curcas is a deciduous plant. In the state of Tocantins, it is known to sprout during the rainy season, or when plantations are irrigated. Between May and October, when there is little or no rainfall in this region and temperatures are high (Fig. 1), the plants lose part of their leaves and enter dormancy (SARAIVA et al., 2013). Nonetheless, mite richness, diversity, and abundance were the highest in the top stratum.

High rainfall may decrease the population density of phytophagous mites, possibly due to contact of raindrops with the colonies (RÊGO et al., 2013). However, in our study, higher mite abundance was observed during the rainy season, which may have relation to the higher number of leaves on $J$. curcas plants. The active vegetative stage of J. curcas plants is related closely to the rainy season (SARAIVA et al., 2013). This therefore suggests that rainfall, together with the presence of leaves, could be the determining factor for mite occurrence on J. curcas plants.
In the present study, phytophagous and predatory mite occurrences on J. curcas plantations were influenced by seasonality and followed the same distribution trend, with higher populations being observed during the rainy season. Our results are consistent with previous studies that evaluated phytophagous and predatory mite occurrence in the state of Tocantins (CRUZ et al., 2012; 2013b; ROSADO et al., 2015b). In addition, our results can provide a basis for the development of new sampling procedures for phytophagous and predatory mites in J. curcas plantations.

Finally, our data show that phytophagous and predatory mites colonizing J. curcas are especially concentrated in the top canopy stratum.

\section{ACKNOWLEDGMENTS}

We thank to Coordination for the Improvement of Higher Education Personnel (Coordenação de Aperfeiçoamento de
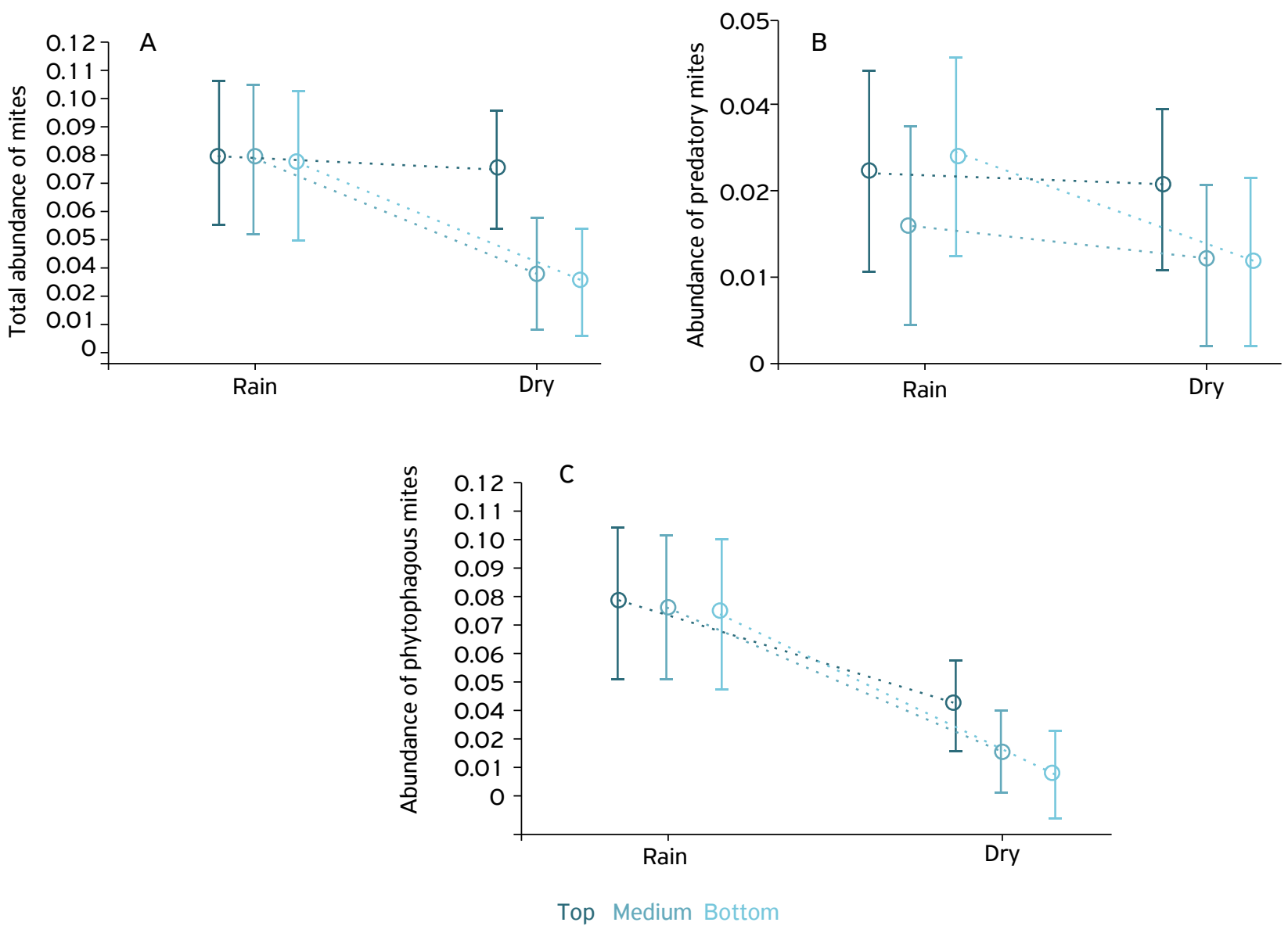

Figure 4. (A) Total mite abundance (stratum: $F_{2,717}=2.22, p=0.10$; season: $F_{1,717}=8.02, p=0.005$; season*stratum: $F_{2,717}=$ $0.51, p=0.59$ ); (B) predatory mite abundance (stratum: $F_{2,717}=0.95, p=0.38$; season: $F_{2,717}=1.97, p=0.16$; season* stratum: $F_{2,717}=0.51, p=0.59$ ); $(C)$ phytophagous mite abundance (stratum: $F_{2,717}=0.93, p=0.39 ;$ season: $F_{1,717}=27.86, p=0.0001$; season*stratum: $\left.F_{2,717}=0.42, p=0.65\right)$. Untransformed data. 
Pessoal de Nivel Superior - CAPES) (Projects: Programa Nacional de Cooperação Acadêmica - PROCAD 2013; Programa Nacional de Pós-Doutorado - PNPD), the Brazilian National Council for Scientific and Technological Development (Conselho Nacional de Desenvolvimento Científico e Tecnológico - CNPq), and the Federal University of Tocantins (Universidade Federal do Tocantins - UFT), for financial support. Althiéris S. Saraiva acknowledges the Instituto Federal de Educaçáo, Ciência e Tecnologia Goiano - Campus Campos Belos - for support and partnership. Renato A. Sarmento received scholarship from CNPq (Projects: 304178/2015-2; 200895/2015-0).

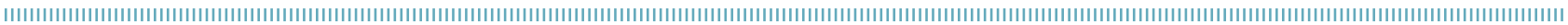
REFERENCES

ALONSO, O.; LEZCANO, J.C. Artrópodos asociados a Jatropha curcas Linnaeus. Funciones y estrategia para su manejo. Pastos y Forrajes, Matanzas, v.37, n. 1, p.03-16, 2014.

BOLLAND, H.R.; GUTIERREZ, J.; FLECHTMANN, C.H.W. World catalogue of spider mite family (Acari: Tetranychidae). Leiden: Brill, 1998. 392p.

CHANT, D.A.; MCMURTRY, J.A. A review of the subfamilies Phytoseiinae and Typhlodrominae (Acari: Phytoseiidae). International Journal of Acarology, West Bloomfield, v.20, n.4, p.223-310, 1994.

CRUZ, W.P.; RODRIGUES, D.M.; SARMENTO, R.A.; FERREIRA JUNIOR, D.F.; RIBEIRO, F.R. Avaliação da diversidade de plantas espontâneas e a densidade de ácaros predadores em cultivo de pinhão-manso. Revista Brasileira de Agroecologia, Porto Alegre, v.8, n.2, p.176-184, 2013 a.

CRUZ, W.P.; SARMENTO, R.A.; TEODORO, A.V.; ERASMO, E.A.L.; NETO, M.P.; IGNACIO, M.; FERREIRA JUNIOR, D.F. Acarofauna em cultivo de pinhão-manso e plantas espontâneas associadas. Pesquisa Agropecuária Brasileira, Brasília, v.47, n.3, p.3 19-327, 2012.

CRUZ, W.P.; SARMENTO, R.A.; TEODORO, A.V.; NETO, M.P.; IGNACIO, M. Driving factors of the communities of phytophagous and predatory mites in a physic nut plantation and spontaneous plants associated. Experimental and Applied Acarology, Amsterdam, v.60, n. 1, p.509-519, $2013 \mathrm{~b}$.

FERES, R.J.F.; RUSSO, V.; DAUDET, R.D. Diversidade de ácaros (Arachnida: Acari) em Hymenaea martiana (Leguminosae) em gradiente de tamanho de plantas. Biota Neotropical, Campinas, v. 10, n.4, p. $119-126,2010$.

FERLA, N.J.; MARCHETTI, M.M.; GONÇALVES, D. Ácaros predadores (Acari) associados à cultura do morango (Fragaria sp., Rosaceae) e plantas próximas no Estado do Rio Grande do Sul. Biota Neotropical, Campinas, v.7, n.2, p.103-110, 2007.

GERSON, U.; FAIN, A.; SMILEY, R.L. Further observations on the Cheyletidae (Acari), with a key to the genera of the Cheyletinae and a list of all known species in the family. Entomologie, v.69, p.5-86, 1999.

HALLIDAY, R.B.; WALTER, D.E.; LINDQUIST, E.E. Revision of the Australian Ascidae (Acarina: Mesostigmata). Invertebrate Taxonomy, v.12, p.01-54, 1998.
LOFEGO, A.C. Caracterização morfológica e distribuição geográfica das espécies de Amblyseiinae (Acari: Phytoseiidae) no Brasil. 167p. Dissertation (Mestrado em Zoologia) - Instituto de Biociências da Universidade de São Paulo, São Paulo, 1998.

LOFEGO, A.C.; REZENDE, J.M.; VERONA, R.L.C.; FERES, R.J.F. Mites (Acari) associated with three species of the genus Jatropha (Euphorbiaceae) in Brazil, with emphasis on Jatropha curcas. Systematic and Applied Acarology, London, v. 18, n.4, p.41 1-412, 2013.

MORAES, G.J.; MCMURTRY, J.A.; DENMARK, H.A.; CAMPOS, C.B. A revised catalog of the mite family Phytoseiidae. Auckland: Magnolia Press, 2004. 494p. (Zootaxa 434).

MORAES, G.J.; FLECHTMANN, C.H.W. Manual de acarologia: acarologia básica e ácaros de plantas cultivadas no Brasil. Ribeirão Preto: Holos, 2008. 308p.

PEDRO-NETO, M.; REIS, P.R.; ZACARIAS, M.S.; SILVA, R.A. Influência do regime pluviométrico na distribuição de ácaros em cafeeiros conduzidos em sistemas orgânico e convencional. Coffee Science, Lavras, v.5, n. 1, p.67-74, 2010.

PEDRO-NETO, M.; SARMENTO, R.A.; OLIVEIRA, W.P.; PICANÇO, M.C.; ERASMO, E.A.L. Biologia e tabela de vida do ácaro-vermelho Tetranychus bastosi em pinhão-manso. Pesquisa Agropecuária Brasileira, Brasília v.48, p.353-357, 2013.

PRITCHARD, A.E.; BAKER, E.W. A revision of the spider mite family Tetranychidae. San Francisco: Pacific Coast Entomological Society, 1955. 472p. (Memoirs Series Volume 2).

RÊGO, A.S.; TEODORO, A.V.; MACIEL, A.G.S.; SARMENTO, R.A. Relative contribution of biotic and abiotic factors to the population density of the cassava green mite, Mononychellus tanajoa (Acari: Tetranychidae). Experimental $\odot$ Applied Acarology, Amsterdam, v.60, n.4, p.479-484, 2013.

ROSADO, J.F.; PICANÇO, M.C.; SARMENTO, R.A.; PEREIRA, R.M.; PEDRO NETO, M.; GALDINO, T.V.S.; SARAIVA, A.S.; ERASMO, E.A.L. Geostatistics as a tool to study mite dispersion in physic nut plantations. Bulletin of Entomological Research, Cambridge, v.105, n.4, p.381-389, 2015 a.

ROSADO, J.F.; PICANÇO, M.C.; SARMENTO, R.A.; SILVA, R.S.; PEDRONETO, M.; CARVALHO, M.A.; ERASMO, E.A.L.; SILVA, L.C.R. Seasonal variation in the populations of Polyphagotarsonemus latus and Tetranychus bastosi in physic nut (Jatropha curcas) plantations. Experimental and Applied Acarology, Amsterdam, v.66, p.415-426, 2015b. 
ROSADO, J.F.; SARMENTO, R.A.; PEDRO-NETO, M.; GALDINO, T.V.S.; MARQUES, R.V.; ERASMO, E.A.L.; PICANÇO, M.C. Sampling plans for pest mites on physic nut. Experimental and Applied Acarology, Amsterdam, v.63, n.4, p.521-534, 2014.

SARAIVA, A.S.; DORNELAS, D.F.; DORNELAS, B.F.M.; GONÇALVES, R.C.; ERASMO, E.A.L.; SARMENTO, R.A.; NUNES, T.V. Crescimento e produção de pinhão-manso (Jatropha curcas L.) sob doses de fósforo. Journal of Biotechnology and Biodiversity, Gurupi, v.4, n.3, p.240-248, 2013.

SARAIVA, A.S.; SARMENTO, R.A.; ERASMO, E.A.L.; PEDRO-NETO, M.; SOUZA, D.J.; TEODORO, A.V.; SILVA, D.G. Weed management practices affect the diversity and relative abundance of physic nut mites. Experimental and Applied Acarology, Amsterdam, v.65, n.3, p.359-375, 2015.

SARMENTO, R.A.; RODRIGUES, D.M.; FARAJI, F.; ERASMO, E.A.L.; LEMOS, F.; TEODORO, A.V.; KIKUCHI, W.T.; SANTOS, G.R.; PALLINI, A. Suitability of the predatory mites Iphiseiodes zuluagai and Euseius concordis in controlling Polyphagotarsonemus latus and Tetranychus bastosi on Jatropha curcas plants in Brazil. Experimental and Applied Acarology, Amsterdam, v.53, n.3, p.203-214, 2011.
SHANNON, C.E. A mathematical theory of communication. Bell System Technical Journal, v.27, p.379-423, 1948.

SOURASSOU, N.F.; SARMENTO, R.A.; MORAES, G.J. Description of a new species of the Amblydromalus limonicus (Acari: Phytoseiidae) species group based on morphological and molecular evidences. International Journal of Acarology, St. Albans, v.43, n.5, p.374379, 2017.

SPONGOSKI, S.; REIS, P.R.; ZACARIAS, M.S. Acarofauna da cafeicultura de cerrado em Patrocínio, Minas Gerais. Ciência Agrotecnológica, Lavras, v.29, n.1, p.9-17, 2005.

WELBOURN, W.C.; OCHOA, R.; KANE, E.C.; ERBE, E.F. Morphological observations on Brevipalpus phoenicis (Acari: Tenuipalpidae) including comparisons with $B$. californicus and $B$. obovatus. Experimental and Applied Acarology, v.30, p.107-133, 2003.

ZUNDEL, C.; NAGEL, P.; HANNA, R.; KORNER, F.; SCHEIDEGGER, $U$. Environment and host-plant genotype effects on the seasonal dynamics of a predatory mite on cassava in sub-humid tropical Africa. Agricultural and Forest Entomology, London, v.11, n.3, p.321-331, 2009 . 